\title{
Implications of Multitudinous Multilateral Institutions for Southeast Asia
}

\author{
Prof. Y Yagama Reddy*
}

\begin{abstract}
The strategic location of Southeast Asia which served as a centripetal force all through the history has acquired primacy in all the geopolitical doctrines. With the initial attempts at regional integration ended in fiasco, ASEAN came into existence in 1967 for achieving regional cohesion and economic development. Following a prolonged hibernation, ASEAN has ultimately evolved onto the flank of 'one region-one vision.' In the context of the imperatives of new global order, there has begun the proliferation of regional organizations/groupings centering on Southeast Asia transgressing the political and regional boundaries. Besides APEC, ARF, BIMSTEC, MGC, ASEAN+3, ASEAN+1, AEM, EAS and CSCAP, there are a plethora of multilateral arrangements encompassing FTAs and RTIAs and other initiatives. There are also confidencebuilding and security mechanisms could at the best cause further swelling to the heap of regional bodies.
\end{abstract}

The constellation of regional bodies, by virtue of overlapping, would subscribe to the complexity and trust-deficit that may undermine the potential benefits and prospects. These multilateral mechanisms may likely to face rough weather in the context of their interests getting clashed with others and the threats from certain intrinsic weaknesses and dissensions. That the extraregional powers hardly desist from their temptation of gaining access to this region's resources and strategic advantages would certainly jeopardize the expected prospects of multilateral institutions. This proliferation of regional bodies reminds one of the European alliance systems preceding the First World War; and it is feared that Southeast Asia would meet the same fate as the Balkan states in the $19^{\text {th }}$ century as if being qualified for the title of "Balkans of the East."

Keywords: Regional Integration, ASEAN, conflict of interest, multilateral cooperation, Balkan States, European Alliance, Confidence building, FTA, RTIA

* Prof. Y Yagama Reddy is UGC Emeritus Fellow (2015-2017), Centre for Southeast Asian \& Pacific Studies, Sri Venkateswara University, Tirupati, India. 


\section{Implications of Multitudinous Multilateral Institutions for Southeast Asia}

\section{Introduction}

Southeast Asia, reckoned as an entity per se, portrays an apparent regional homogeneity that tends to differentiate the region from the other regions of Asian continent as well as from the island realm in the central and South Pacific region. Yet, the unity and boundedness seem to be the mere perceptions, if the subtle variations in the physical and human environment of the region are of any indication (Fisher 1966). Thus, Southeast Asia has become a realm of contrasts in view of the complexity and diversity in many aspects (Dutta 1985), which inspired certain descriptive epithets like cultural shattered belt, bridge and barrier, Balkans of East, political fault zone and a region at the crossroads. All these connotations, in a way, point to the Southeast Asia's location at the crossroads that had facilitated the human contact, and settlement and the cultural expansion.

\section{Southeast Asia: A Realm of Contrasts Predisposed to Geographical Causation}

The historic southward migrations from southern China through the narrow constricted river valleys resulted in the displacement of earlier settlers in Southeast Asia. These new comers, essentially of Mongoloid race, began to emerge as the dominant ethno-linguistic groups in the disjointed fertile tracks and consolidated their political base in different parts of Southeast Asia-Mons, Karens, Shans and Burmans in Myanmar, Siamese in Thailand, Laotians in Laos, Khmers in Cambodia, Viets in Vietnam and Malays in the archipelagic region. It was the maritime geography that was at the base of the cultural evolution accomplished through the process of Indian cultural expansion into Southeast Asia across the Bay of Bengal which posed no major climatic obstacles. The spread of Indian culture was an extensive rather pervasive spatio-temporal phenomenon sustained for about 1500 years from the beginning of the Christian era. The spread of Hinduism and Buddhism into the mainland Southeast Asia as well as Islam into the Malay-Indonesian archipelago was accomplished through a process utterly divorced from political conquest and economic exploitation. 
The geographical nodality of Southeast Asia made the region become vulnerable to European domination in the form of colonisation. The new economic opportunities of colonial administration attracted the large scale immigrations of Chinese, Indians and Europeans in the 19th and the early 20th centuries. Thus, Southeast Asia had become a bridge and a barrier to a wide range of human contact, movement and ideas. This process of fusion and fracture of ethnic and cultural mores turned the region into a politico-cultural fault zone resulting in the formation of plural societies in every country. Yet, the Indian cultural elements survived the period of transition and instability; and the peoples and the leaders of Southeast have time and again acknowledged India's splendid contribution to their glorious cultural history of Southeast Asia. The Southeast Asian region, besides harbouring four major religious faiths-- Buddhism, Hinduism, Islam and Christianity, has also a variety of hill people with wide range of animistic beliefs. Even as Southeast Asia exhibits conspicuous variations in its population distribution pattern, the region has fourth populous country, Indonesia with 261.1 million (next to China, India and Russia) and the least populated country, Brunei (0.423 million), as per the UN statistics (United Nations Department of Economic and Social Affairs 2017). Aside from Singapore with phenomenally high density of population (7671 persons/ $\mathrm{km}^{2}$ ), Southeast Asia has profound variations in density ranging from 338 (the Philippines) to 30 (Laos).

\section{Etymology of Southeast Asia: Rhetoric}

Notwithstanding the glorious past of the region, the term 'Southeast Asia' is comparatively of a recent origin. The pre-modern kingdoms were totally eclipsed by the states carved by the Western colonial masters. But, the colonial powers primarily concerned with the economic benefits from their colonial enterprises. Their abject indifference led to the loose or liberal use of the term, 'Southeast Asia' in multifarious forms. Western scholars looked at the region as a 'culturally shattered belt'; and the Western statesmen considered the issue of nomenclature 'esoteric'. To make the matters worse, the ill-drawn boundaries of European colonial masters, with scant regard to the logic of history, ethnicity and geography, have affected the evolved regional frame of Southeast Asia which has since then been at variance with the ground realities. Surprisingly, it was not the scholarship but the warfare (World War II) that made Southeast Asia popular, thanks to the publication of maps of Southeast Asia in excessively large number (20 
million) by the National Geographic Society. Yet, these maps ignored the logic of compass while delimiting the boundaries of the Southeast Asia Command (SEAC), one of the theatres of World War II. For all this lopsidedness in region-forming process, Southeast Asia was made visible and the nomenclature was legitimized. Even after decolonization, the political map of Southeast Asia was not free from the vestiges of Western colonial rule. The triumph of nationalism and the resultant nation-states overrode any other criterion for evolving regional framework. Many scholars, who could not get reconciled to these glaring inconsistencies in the region-forming factors and processes, tried in vain to suggest the appropriate borders to this region on the basis of religion and history, ethnology and languages, geomorphology, biogeography and political science. The toponym, "Southeast Asia," though in its binomial expression conforms to the logic of geography, does not have any semblance with the grandiosity of region's history; and hence the etymology of Southeast Asia seems to be rhetoric (Yagama Reddy 2005). Historical momentum, being far ahead of these intrinsic realities, made the region contend with the existing borders which almost became the permanent features. Admittedly, historical geography presents a phenomenon of series of dialectical patterns that subscribe to the notion of paradoxes (Yagama Reddy 2004).

\section{Southeast Asia's Regional Setting and its Strategic Significance}

The region's historical momentum had been predisposed to its trans-oceanic location (between the Indian and Pacific Oceans), even as the Himalayas and its related mountain chains act as a formidable barrier for the overland movement of goods and people between the Asian continent proper and Southeast Asia. In its physical character, Southeast Asia is broadly constituted into a peninsula (mainland Southeast Asia) and insular Southeast Asia comprising several thousands of islands of various dimensions. Its area of 9.6 million $\mathrm{km}^{2}$, almost equally divided into land and water bodies (surrounding seas), testifies to a high degree of territorial fragmentation. Nearly three-fourths of land is a rugged mountainous terrain (upland) of variable forest types, leaving behind less than 25 per cent of land in the form of coastal plain, deltas and down-stream valleys of major rivers (lowlands) to support as much as 75 per cent of the population. In consequence, the lowlands have emerged as the centres of political and economic power; and this historical legacy has also contributed to the geopolitical nuances, as outlined by the statesmen and scholars 
concerned with Southeast Asia's strategic pre-eminence vis-à-vis the Asia-Pacific region. The ten countries in the Association of Southeast Asian Nations (ASEAN) are very much varied in their areal extent ranging from the largest one being Indonesia (1826440 sq. km) to the smallest entrepot city, the island nation of Singapore $(683 \mathrm{sq} . \mathrm{km})$. Indonesia is the fifth largest nation in the Asia-Pacific region (preceded by Russia, China, Australia and India, if the latter's membership in East Asia Summit (EAS) is taken into consideration). Based on the membership in ASEAN Regional Forum, Indonesia in its areal extent ranks seventh, next to Russia, Canada, the US, China, Australia and India, if the European Union is excluded from the purview of comparison.

Southeast Asia claims the distinction of having a large archipelagic nation, Indonesia, with about 18000 islands, next only to Canada (30000 islands). Yet another distinction of Southeast Asia lies in its being endowed with the lengthier coastlines of Indonesia $(54176 \mathrm{~km})$ and the Philippines $(36289 \mathrm{~km})$, far ahead of the coastal lengths of some other EAS member states, viz., Japan $(29751 \mathrm{~km})$, Australia $(25760 \mathrm{~km})$, China $(14500 \mathrm{~km})$, if Russia's preponderant coastline abutting the Arctic Ocean is precluded. With an exception of Laos, the land-locked country, all other Southeast Asian countries have variable, but appreciable, coastline-area ratios. The ratios, as could be simply computed by an inquisitive scholar from the basic data on coastline and land area, indicate no relationship with the areal extent; instead they serve to evaluate the degree of accessibility. Higher the ratio, as in the case of Singapore (286.97) and Indonesia (121.97), means higher benefit of accessibility. Singapore with an area of a meagre $683 \mathrm{sq} . \mathrm{km}$. is credited with highest ratio (286.97) vis-à-vis Russia (16377742 and China (9326410 sq. km) with the lowest ratios of 2.22 and 1.56 respectively. The higher ratios (as in the case of the Philippines, Japan and New Zealand) are essentially due to their lengthier coastline and smaller areal extent.

The peninsular shape and the insularity led to the development of several trading ports all along the lengthy coastline. The pervasive maritime environment, besides facilitating a wide range of maritime activities including the trade, had served as a unifying factor than as a divisive force all through the period of history. The maritime trade afforded as much economic strength to many a maritime power as agriculture could have sustained them. The intervening seas and the narrow straits serving as passages of egress have bolstered strategic significance of the South China Sea 
so much as to be termed as the 'geopolitical lake' of the Southeast Asia. Japanese occupation of Southeast Asia during the Second World War made Australia, especially the war-time Prime Minister John Curtin (October 1941-July 1945), perceive the strategic implications of Southeast Asia for Australia, which has thenceforth looked upon its northern neighbourhood as 'a bridge and a barrier' as well as 'a forward zone of defence'. The noted Indian historian, K M Panikkar, too linked India's security to the stability of Southeast Asia. Even all the geopolitical doctrines of the $20^{\text {th }}$ century -- especially those postulated by Mackinder (incorporated this region into the inner/outer crescent of 'heartland' theory), Spykman (structuring the region as part of the 'Rimland') and Truman ('domino' theory) -- had clearly enunciated the geopolitical implications of Southeast Asia. Much in contradiction to the nascent regional identity was the dismemberment of Southeast Asia into three theatres of war during the Second World War-- Southeast Asia Command, China Theatre and Pacific Theatre.

\section{Regional Organizations in Asia: Peculiarity and Paradox}

Asia has enjoyed its peculiarity for having initiated the Asian institution-building efforts in the immediate post-War period. Hosted during this period were three major 'pan-Asian' conferences: the Asian Relations Conference (New Delhi: April 1947), the Baguio Conference (the Philippines: May 1950) and the Colombo Powers Conference (April 1954). Despite several other peculiarities claimed to its credit, the paradox was that the post-war Asia could not evolve an exclusive organization encompassing the entire continent. With nations of varying sizes, different political systems as well as diversity of ethnicities, religions and cultures, Asian continent has long confronted the challenges for creating an Asian Union on the lines of the European Union; and the concept of pan-Asian multilateral regionalism transcending the borders has for long remained rhetoric. The pan-Asian regionalism was also foiled by high economic nationalism in the context of decolonization and weak intra-regional economic linkages owing to lack of complementarity. Though countries like India embarked on the import-substitution manufacturing policy so as to lessen their dependency on other nations, many a newly independent state had their erstwhile colonial masters as their trading partners. It was more of an inability than a failure, largely attributed to factors like: too much obsession with sovereignty that inhibited the collective identities, intra-Asian suspicions coupled with ideological 
differences and divergence on account of Cold War geopolitical equations and the dependence of Asian countries on Western security guarantees in the absence of viable self-help capabilities. It is rather surprising that there was no Asian regional institution that had the ability to deal comprehensively with all of the economic, political and security issues' (Koh 2010).

Therefore, for all its being the largest continent, Asia has for long entertained the lofty-goal of a pan-Asian framework, until and after Asia Cooperation Dialogue (ACD), a continent-wide forum being the first of its kind in Asia, was formed in 2002. (I) Despite the regular Foreign Ministers' annual meetings of ACD, it still endures a sort of hibernation; and this apathy of regional consciousness owes much to the diversity of the region, the different historical backgrounds, the survival of strong extra-regional ties, the different threat perceptions and the political fragility and transition. Thus, Asia stands apart from the other continents, as can be observed from Table-1. Asia, though lacks a long history of regionalism, has become a fertile ground in the recent times for all kinds of regional bodies which, as Kesavapany has commented, testify to limping economic integration process and incipient regional identity (Kesavapany 2005), as in the case of the South Asian Association for Regional Cooperation (SAARC). What is all the more important is the termination of the Cold War that has made Asia an arena for crowded multilateral security arrangements. Interestingly, in the wake of the centre of gravity of the world economy gradually shifting from Europe and North America to Asia in the $21^{\text {st }}$ century, the concept of 'One Asia' and several such other expressions as 'Asian Century,' 'Asian Community,' 'Asian Identity' and 'Asian-ness' have underscored the need for regional integration, rather giving credence to the theme of 'Asian Solidarity.'

Table-1: Organizations with Continental Reach

\begin{tabular}{|l|l|l|}
\hline Continent & \multicolumn{1}{|c|}{$\begin{array}{c}\text { Organization (year of } \\
\text { establishment) }\end{array}$} & Constituent Parts/regions \\
\hline Africa & African Union (1954) & Entire continent (54 countries) \\
\hline South America & South American Union (2004) & Entire Latin America (12 Countries) \\
\hline North America & $\begin{array}{l}\text { North American Free Trade Area } \\
(1994)\end{array}$ & $\begin{array}{l}\text { Canada, USA, Mexico (only 3 } \\
\text { countries) }\end{array}$ \\
\hline Americas & Organization of American States & Both North America and South \\
\hline
\end{tabular}




\begin{tabular}{|l|l|l|}
\hline (both) & $(1948)$ & America \\
\hline Europe & European Union (1952) & Entire continent (27 countries) \\
\hline Oceania* & South Pacific Islands Forum (1971) & 16 island states in the Pacific Ocean \\
\hline
\end{tabular}

*encompasses the island realm in the Pacific Ocean including the island-continent-nation of Australia.

\section{Rationale behind Regional Frameworks}

Even as the 'Region' is a geographically contested concept, there has begun a rising trend in the evolution of regional organizations, in response to the dynamics of global-level economic, political and socio-cultural linkages. The regions of the world, separated so much by history and culture as by physical geographical features, provided the political space. Inasmuch as a region connotes geographical relationship and mutual interdependence linking a limited number of states together, regionalism permits differential levels of integration and institutionalization in accordance with a degree of economic development and interdependence. Suffice it to say, the region forming factors and processes do hardly address the infirmities of regional frameworks mushrooming all over the world in the wake of globalization. Thus, there has arisen the need for focusing on the modus operandi of the regional groupings originated on account of compulsions and compromises testifying to modus vivendi. Regionalism was generally analyzed (as, for instance by $M$. Russett) in terms of geographical contiguity/proximity, social-cultural homogeneity (ethnicity, race, language, religion, culture, history, consciousness of a common heritage), economic interdependence (trade patterns and economic complementarity), political cohesiveness (regime type, ideology, i.e., similar political attitudes and behaviour), and organizational cohesiveness/shared institutional membership (existence of formal regional institutions) (Russett 1967, p.182). In a study on regionalism in Asia-Pacific, Norman D. Palmer, a renowned scholar in international relations and organizations, encapsulated the five characteristics of a region listed by Bruce Russett (Palmer 1991, p.7). While regionalization implies the tendency or process to form regions, regionalism symbolizes the purposive proneness to create regional institutions and arrangements, although both find expression in the economic and security domains, including convergent motivations towards both political/security and economic forms of integration (Fawcett 1995). 
The Second World War and its consequences demolished the old European order. Taking advantage of the provision in the UN Charter, regional bodies had begun to sprout and proliferate during the post-war period, defying the basic tenets of region-forming. Even if the Cold War period crystallized the idea of regionalism as an important dimension of geopolitical milieu, Cold War tensions offered no scope for regional cooperation mechanisms. Initially, the focus of regional bodies in the 1950s and 1960s was on the intra-regional issues and the efforts for regional integration. But, this 'inward looking' old regionalism had begun to be replaced by the 'outward looking' new regionalism in 1980s with focus on external links with other regions, and the inter-regional interactions have become preponderant in the $1990 \mathrm{~s}$.

The post-Cold War globalization has caused a spurt in carving out regions, but with scant regard to the scientific rationale being imminently adopted in any regionalization dialectics. Geoeconomic visions play up the importance of transnational flow of goods and services, capital and labour, and technology and ideas. While the Cold War geopolitical views or discourses are respecified, inclusion of the states in regional groupings toes the competition along the fault lines of geo-economics. Surprisingly, the post-Cold War new economic order, enunciating the interdependence among the nation-states, has driven them to look far beyond their territorial limits. Economic regionalism focuses on the formation of preferential trading arrangements between groups of countries within geographic region. Thus, economic regionalism is discriminatory vis-à-vis the principle of non-discrimination which is the basis of multilateralism. Furthermore, the pursuit of international cooperation-- as a means of finding solutions to a host of contentious issues at the bilateral level or even at the intra-regional level-has led to the proliferation of trans-regional organizations rather multilateral institutions. For all the inherent constraints - intra-regional and inter-regional diversities, differential historical backgrounds, and time-tested strong extra-regional links and varied threat perceptions, besides political instabilityand-transition within the nation - the emerging constellation of major powers and immediate neighbours has become the dominant global scenario. In view of its being as expansive in nature as to sustain external linkages, the new regionalism serves as a potent force in the post-Cold War global order. 
Regionalization, as a manifestation of globalization, presupposes one of the forms, viz., a component of globalization (convergent trend); a challenge or response to globalization (divergent trend); and or a parallel process to globalization (overlapping trend) (Kacowicz 1998). Globalization and regionalization are phenomena that form part of an historical process to the extent of shaping and enlivening the latter. The relationship between globalization and regionalization also offers distinction between de facto economic integration and de jure political institutionalization (Higgott 1999, p.91). If regionalism is emerging today as a potent force in the process of globalization rather as a chapter of globalization (Yeo 2005), regionalization is a process towards the end of integration. Further, complexity and diversity of the region accompanied by diverse needs and competing interests defying the prospects of evolving a panAsian organization have become conducive to the proliferation of regional organizations. The plethora of regional arrangements, bearing testimony to laissez faire approach, tends to ignore the geographical limits so much as to render regionalism a diffused and unmanageable phenomenon. Yet, the momentum gained for strengthening multilateral arrangements is justified that a single-region focus is inadequate. Further, multitude of regional cooperative mechanisms is looked upon as a prelude to the emergence of multi-polarity that is expected to foster global level stability.

\section{Southeast Asia: From 'One-Region-One Vision' to the Stage of Multilateralism}

Southeast Asia's strategic location as convergence of international air and sea lines of communications lured the major external powers so much as to entertain vested interests of their own. Even as Southeast Asian countries were treading the path of emerging as independent nation-states, the region had unwittingly become an amphitheatre of the Cold War confrontation, spearheaded by the two super-powers which used the region for proxy wars and major power rivalry. Southeast Asia Treaty Organization (1954) and Second Indochina War (1960-75), as manifestation of Cold War, thwarted the attempts at consolidating the regional framework of Southeast Asia. If the first two indigenous regional organizations (ASA and MAPHILINDO) ended in a fiasco, Association of Southeast Asian Nations (ASEAN) was formed in August 1967 with well-stated objective of maintaining "close and beneficial cooperation with existing 
international and regional organizations with similar aims and purposes," by embarking on the strategy to make Southeast Asia the fulcrum for the new architecture of peace and cooperation.

ASEAN, the first ever indigenous Asian organization, too endured structural stagnation rather lack of regional cohesion for over two-and-a half decades until the termination of Cold War close on the heels of collapse of the Soviet Union. The long-felt dream of 'one-region-one vision' was realized with the evolution of ASEAN as a full-fledged regional organization (A-10) encompassing all the Southeast Asian countries. Though there were 52 ASEAN Foreign Ministers Meetings (AMM) held regularly (the last one in Bangkok on 29 July - 2 August 2019) over the past 52 years of ASEAN-existence, there had been only 35 Summits (the latest on in Bangkok on 1-4 November 2019) organized with pronounced intermittent gaps, especially during the period until 1990s. ${ }^{\text {(II) }}$ The inconsistency in holding the Summits in a way points out the hiccups and the Cold War fallout that belittled the expectations of ASEAN. ASEAN's commitment to non-interference, informality, minimal institutionalization, consultation and consensus, non-use of force and non-confrontation is popularly known as the ASEAN Way, which has more often than not proved itself successful in the resolution of certain contentious issues.

In deference to the ASEAN's conviction that "its long-term security is tied with the overall security outlook of the Asia-Pacific region" and that the "developments in one of the regions could have an impact on the security of the region as a whole," ASEAN Regional Forum (ARF) was founded in 1994 "to promote political and security dialogue and cooperation in the AsiaPacific region, with particular emphasis on East Asia, through the promotion of confidencebuilding measures and preventive diplomacy" (Severino 2011). Thus, ARF was the product of ASEAN's realization of security concerns entailing the rise of China and problems of economic interdependence between Southeast Asia and Northeast Asia. Though ARF is varied from the ASEAN in the geographical scope, ARF was basically an ASEAN-modeled one, by adopting ASEAN's Treaty of Amity and Cooperation as its normative framework and the "ASEAN Way" of flexible consensus in its organizational simplicity. British withdrawal from the region and uncertainties about the US military presence in the region owed to the origin of ARF, which was thus equally concerned with engaging the US and China. ARF, a unique regional forum on 
regional political and security issues in the Asia-Pacific, is considered an equivalent of the Organization for Security Cooperation in Europe (OSCE). ARF has 27 participants ${ }^{\text {(III) including }}$ some external rival states like China-Japan, North Korea-South Korea, and India-Pakistan. ARF has the reputation of keeping the hard security challenges off the Agenda.

If $\mathrm{ARF}$ is considered as a multilateral initiative to engage China, ASEAN+3 is yet another initiative of ASEAN intended to unite Northeast Asia and Southeast Asia. Intra-regional economic ties and Asian regional identity led to the formation of ASEAN plus Three (APT) (ASEAN + China, Japan and South Korea) in 1997. The APT process with ASEAN as the driving force is looked upon as a main vehicle to achieve the long-term goal of building an East Asian Community and to contribute to the sustainable development in the region. ASEAN-India relationship was elevated to the Summit level in 2002 (Phnom Penh, Cambodia); and the Summit meetings (ASEAN+1), held annually, signify the importance of the dialogue partnership to ASEAN and India, due in large part to India's Look East Policy launched in 1992. Consequent upon the decision to this effect by the ASEAN Foreign Ministers at the Cebu (the Philippines), countries outside the East Asia region, viz., India, Australia and New Zealand, participated in the inaugural East Asian Summit (EAS). Being a more inclusive organization than ASEAN+3, EAS is considered as a mid and long term measure for realizing an East Asia Community. Thus, with EAS accommodating a larger geographical area, the traditional geographical definition of East Asia was so much expanded to define a region more in political terms. Even as ASEAN +3 and the EAS are being considered as the two most relevant institutions for building the East Asian Community, yet another multilateral initiative, JACIK (Japan-ASEAN-China-India-South Korea), came into existence for the purpose of harnessing economic complementarities towards fostering the economic cooperation and thereby the regional growth and development. The great dynamism of cooperation in various fields exhibited by the ASEAN-led initiatives has no doubt portrayed the spirit of community-building process, conforming to the ASEAN way.

\section{ASEAN-led Multilateral Processes}

Multiplicity of regional groupings, as could be gleaned from Table-2, has become synonymous with overlapping membership of countries from both within and outside the region as well as 
certain glaring anomalies defying the spirit of regionalism. ASEAN has the distinction of being omnipresent at sub-regional, regional, trans-regional levels, either as a whole body of 10 members or some of its members. In the process, these regional bodies, especially the transregional organizations-like Bay of Bengal Initiative for Multilateral Scientific \& Technical Cooperation (BIMSTEC), Asia-Pacific Economic Cooperation (APEC), ASEAN Regional Forum (ARF), ASEAN-plus-Three (APT), ASEAN+1, Mekong-Ganga Cooperation (MGC) and East Asia Summit (EAS)-- remind us of the factors of mathematical equations or the compounds produced out of chemical reactions.

Table-2: Regional Organizations with Overlapping Membership (with reference to ASEAN)

\begin{tabular}{|c|c|c|}
\hline Grouping & No. of Membership Countries & Anomalous Feature \\
\hline ASEAN & All Southeast Asian countries & --- \\
\hline ARF & 27 countries inclusive of ASEAN & 17 countries all over the world \\
\hline ASEAN+3 & 10 ASEAN countries +Three & $\begin{array}{l}\text { China, Japan and South Korea-extra-regional } \\
\text { states }\end{array}$ \\
\hline ASEAN+1 & 10 ASEAN countries + One & India is essentially a South Asian country \\
\hline JACIK & ASEAN+3+1 & A prelude to EAS \\
\hline EAS & ASEAN+3+3 & $\begin{array}{l}\text { India, Australia and New Zealand, like China, } \\
\text { Japan and South Korea, extra-regional states. }\end{array}$ \\
\hline ACD & 34 Asian countries (+ all ASEAN) & 18 Asian countries NOT members \\
\hline APEC & 21 Pacific-rim states (+ all ASEAN) & Countries in SPIF NOT members of APEC \\
\hline ASEM & $\begin{array}{l}46 \text { countries in Asia and Europe } \\
\text { (inclusive of ASEAN+3) }\end{array}$ & $\begin{array}{l}\text { Yet, EU and ASEAN Secretariat are members } \\
\text { in ASEM }\end{array}$ \\
\hline CSCAP & 20 members + EU (+7 ASEAN) & $\begin{array}{l}\text { EU not part of Asia-Pacific; NOT all the } \\
\text { Pacific-rim states are members }\end{array}$ \\
\hline BIMSTEC & 7 states (5 South Asia+2 ASEAN ) & Excluded 2 Bay of Bengal littorals \\
\hline MGC & 6 states (India+5 ASEAN members) & $\begin{array}{l}\text { NOT all the riparian states of Mekong-Ganga } \\
\text { basin in MGC }\end{array}$ \\
\hline
\end{tabular}

$\mathrm{ACD}=$ Asia Cooperation Dialogue

ASEM = Asia-Europe Meeting 
CSCAP $=$ Council of Security Cooperation in Asia-Pacific

$\mathrm{EU}=$ European Union

JACIK = Japan-ASEAN-China-India-South Korea

SPIF $=$ South Pacific Islands Forum

It is about the same time that some other multilateral settings with no participation of ASEAN have a direct bearing on the ASEAN's vitality, especially on the security-related issues. Mention may be made of the Shanghai Cooperation Organization (China, Russia, Kazakhstan, Kyrgyzstan, Tajikistan and Uzbekistan), Northeast Asia Cooperative Dialogue (China, Russia, South Korea, Japan and the US to discuss Northeast Asia security issues), and Six-Party Talks (an unofficial "track-two" forum for government officials, military officers, and scholars from the United States, Russia, China, Japan, South Korea and North Korea to discuss North Korea nuclear issue in conjunction with regional security issues). The Sino-centric new politicaleconomic order in Asia rather Chinese model of "development-minus-democracy" gains ground in Central Asia, through the formation of Shanghai Cooperation Organization (SCO), which is critically known as NATO of the East or Monroe Doctrine of China.

There are certain other incongruous aspects in the ASEAN-based multilateral organizations and settings. The multilateral processes have much less binding force, given the fact that the organizations like ARF and ASEAN+3, though aimed at creating a normative influence on the actions of their members, are yet to develop the mechanisms to enforce them. If ARF aims to promote political and security dialogue and cooperation in the Asia-Pacific region, with particular emphasis on East Asia, through the promotion of confidence-building measures and preventive diplomacy, CSCAP is a superfluous multilateral initiative, though its being a nongovernmental (second track) process for dialogue on security issues in Asia Pacific.

EAS is considered as an appendage of ASEAN which, in reality, is a forum for discussions. As logical corollary, EAS also carries the stigma of a talk shop. In fact, EAS concept of 'shared interests' is outshined by a serious territorial conflicts and competition among leading powers, diverse economic and political systems, and deep religious and cultural divides. It is also largely feared that the EAS would further lose its East Asian identity, if Russia, the United States and 
Canada are admitted as its members; in such an event the proposed East Asia Community would be nothing more than the APEC (Rajan 2011). Yet another multilateral initiative, considered as being 'surplus to requirements', is JACIK (Japan-ASEAN-China-India-South Korea $=\mathrm{ASEAN}+3+1$ ) which is nothing more than a lateral expansion of ASEAN+3 or an antecedent to East Asia Summit (ASEAN+3+3). The stock-justification is in terms of complementary strengths of the member-states becoming conducive to economic cooperation and facilitating capital-and-investment-flows and thereby to regional integration. Setting aside the justification, JACIK and EAS are as much super-structures over the ASEAN+3 as the multilateral institutions with added advantages over the ASEAN+3.

Even as China weighs multilateralism as the panacea for the 21 century's security problems, China has preference for ASEAN+3 in lieu of EAS in steering the regional multilateral processes. For all evidence of China's growing interest in multilateral cooperation with its neighbors, China's primary motivation is to reassure its neighbours and the United States about its benign intentions and to build a reputation as a "responsible power," but also eventually to replace the US-centered system of bilateral alliances with a cooperative security architecture in which it plays a leading role. China's multilateral diplomacy portrays its intention of growing "stronger without provoking others to combine against it," even as suggesting the other Asian countries to ensure protection through institutionalized multilateral settings. Interestingly, PRC has joined India in supporting 'multilateral cooperation mechanisms in Asia' and viewing positively each other's participation in the cross regional, regional and sub-regional cooperation processes in Asia. About the same time, the multilateral bodies devoid of mechanisms to restrain China have begun to consider the alternative proposals of seeking the support from other militarily stronger power as, for instance, the US.

\section{Proliferation of Multilateralism in Southeast Asia and its Implications}

\section{Positive Features}

Admittedly, the multiplicity of organizations is a sign of dynamism and is also considered as "strength of freedom-loving nations." ASEAN-led multilateral bodies remain attractive and useful as well as retain their comparative advantages in the area of security for the countries 
concerned. ASEAN is a regional grouping of small and medium-sized nations that seeks to navigate through the choppy waters of great powers politics. Though ASEAN shares with the EU the merit of being a relatively successful regional organization, "ASEAN Way" is a unique and, in the Asian context at least, more effective approach to institution-building than European-style multilateral interactions (Acharya 2000). The substantial advantages vis-à-vis apprehensions, as envisioned by the member-states, include: strategies for modernization, national identities being compassionate towards neighbouring countries as partners rather than threats, progression in bilateral relations to keep the territorial disputes and other problems aside, and reconciliation of the US dominance not as an impediment to the evolution of regional balance of power. A strong ASEAN, committed to the pursuit of zone of peace and prosperity, is largely expected to serve as the driving force for the community and maintaining a balanced approach to mitigate tensions between China and Japan. Though the US historical ambivalence contributed to the emergence of ASEAN as a mechanism of regional diplomacy, ASEAN has taken onto its shoulders the task of revitalizing regional multilateralism (Acharya and Tan 2006).

The ASEAN's talk shop function is still of some value, as evident from the effective handling of the territorial disputes in the South China Sea by both the meetings of ASEAN foreign ministers and ARF in July 2011. Then, China and ASEAN agreed on a set of guidelines to better implement their 2002 Declaration on the Conduct of Parties in the South China Sea (DOC). This is in quite contrast to Beijing's South China Sea policy insisting more on bilateral negotiations among the claimants concerned than treating it as a multilateral issue (Fang 2011; Singh 2011). ASEAN could elicit the Obama administration's commitment to the region, epitomized by the slogan 'The US is back in Asia,' much in contrast to the Bush administration's version 'the US has its own interest in Asia.' China and ASEAN countries have also pledged to carry out a series of cooperative projects pending the final settlement of the boundary dispute (Terada 2011). Yet, the states are conscious of the impact of interdependence on their domestic and foreign policies in the form of losing their autonomy and mutual suspicion. Unlike the subordinated modality of mercantilism, which relied on the methods of war, geo-economics is identified with the weapons of commerce. The economic interdependence, besides being compatible with trade liberalization, is conducive to the peace and stability; thus the spirit of commerce, as argued by the German 
philosopher, Immanuel Kant, defies the war, inasmuch as the nation-states rely more on the pacific means of conflict-resolution than on the lines of warfare.

\section{Limitations}

Multilateralism at its best, evidently a multi-player game played in a spirit of give-and-take, is a sign of dynamism; and its worst, the multiplicity of organizations shows a degree of residual or latent distrust, rivalry and a game of one-upmanship in the region. Regional organizations, which remain merely a collection of nation states, could hardly address the regional peculiarities that could hinder the prospects of the much expected regional integration.

ASEAN Way: a Liability: Sworn commitment to the ASEAN way, especially the principle of non-interference in the internal affairs of other countries, is a liability for itself. Its inability in conflict resolution and crisis management within the region was well exposed by the East Timor crisis (1999), widespread uprising against the military junta in Burma (2007), the 1997 coup in Cambodia that undermined the 1991 Paris Peace Agreement, recurrent political coups and vandalism in Thailand, and large-scale arson and riots in Indonesia. Although ASEAN remains "the most centrally positioned of all of these organizations, its role (by default) as the regional engine of multilateralism is waning," in the light of alleged low-performanceexpectations and a leisurely pace of change (Job and Williams 2008).

'Talk Shops': An integrated EAC on the lines of EU is a fond-hope rather rhetoric, given the historical animosity, territorial disputes, diverse political systems, subterranean obsession with national sovereignty and varied preferences for alliances. Furthermore, the tendency of one or more countries either to dominate the regional body or to transform the regional organizations into alliances / security pacts would certainly undermine the regional stability and eventually tarnish the image of the multilateralism. Regional and sub-regional organizations, though serve as potentially interesting partners in conflict management, often fail to live up to expectations due to several weaknesses which, as Wulf (2009) listed, include: lack of common values, contested sovereignty, overlapping responsibilities, lack of capacity and dominant regional powers. ${ }^{(i v)}$ Evidently, ASEAN and ARF remain reluctant to give up 
sovereignty rights and take on a peacekeeping role; and hence, there is little prospect of establishing a pan-Asian multilateral regionalism. ASEAN-led regional organizations particularly ARF, typified by 'soft regionalism,' are often ridiculed as essentially toothless 'talk shops;" and ASEAN and the ARF work through consultations, dialogue and consensus. Though $\mathrm{ARF}$ is expected to perform effectively so much as to diffuse the disputes, the objective is unlikely to achieve as long as China and Japan are at loggerheads for Asia-Pacific leadership. It is the Sino-Japanese rivalry that has been attributed to the proliferation of preferential trade agreements in abundance. ARF's limited powers, inadequate institutional backup, sporadic meetings, and a large and disparate membership have made decision-making cumbersome and cohesion problematic (Richardson 2005).

Wary of China's Dominance: Though the Southeast Asian region would not face a possible threat of external interference in the wake of detente among the regional powers, there is competition among the regional and external states for the economic and trade benefits, access to natural resources and markets of export-goods and of services as well as contest over political, cultural and other forms of influence. Even as a vast majority of the countries are wary of China, there is lack of threat perception and great power-cooperation either to get them united or to part their national sovereignty with a supra-national body. On its part, China sees multilateralism as an effective antidote to U.S. unilateralism and bilateralism in Asia and the world; but, most Asian countries have no desire to live in a China-led or China-dominated Asia, nor do they want to replace American hegemony with Chinese domination over their countries; instead, they have begun viewing the U.S. presence in the region to insulate themselves against any future bid by China to re-establish "East Asia Co-prosperity Sphere” (Malik 2007).

ASEAN Balancing 'Play': The smaller ASEAN countries within the ASEAN + 3 framework, concerned with possible dominance by China or Japan, overtly seek to "play" one big power against the other (Tan 2011), as evident from the candid support of some members to the participation of India, Australia and New Zealand in EAS as well as to the US presence in the region. China strongly advocates that "regional integration should be promoted by the countries in the region, with characteristics of the region and suited to the needs of the region." Implicitly, it points to the geographical location of India in the Indian Ocean and that of Australia and New 
Zealand as being not part of East Asia. Beijing is explicit in its apprehensions that the ASEAN members are propping up the non-East Asian countries to balance the rising China and that the US commitment to containing China through its allies, Japan and Australia, and its partners like India. This is quite contrary to China's well expressed intention of joining India and favouring each other's participation in regional organizations across Asia. Similarly, China at a later stage got reconciled to the US presence in the region keeping in mind the wishes of ASEAN members, even as proscribing the deeper US involvement in the region. There is yet another instance of China's stand-point on which China took almost a U-turn. China took the lead in expanding the agenda as to include the political and security issues, far beyond the APT's agenda being wellconfined to economic matters. The People's Daily has vehemently commented India for 'encircling' China through its Look East Policy and exploiting 'Beijing-Tokyo rift' and the Look East Policy as being born out of failure of India's Cold War strategy. The New Delhi's 'polycentric' security concept for East Asia opposes the possible domination of any country over the regional security architecture as well as the creation of any 'ineffective sub-regional security arrangements.' Beijing on the other hand subscribes to a 'regional security environment of mutual trust, guaranteeing stability by bridging differences through dialogue on an equal footing,' and prefers security mechanisms at different levels and in different areas (Rajan 2011).

Geopolitics of Globalization: East Asia Community, being sprung up from the ASEANled processes like ARF, APT, JACIK and EAS, reminds the predicament of Europe in the $19^{\text {th }}$ and early $20^{\text {th }}$ centuries. But, unlike the great powers of Europe which were experiencing powerregression from the beginning of the 20th century, Asia at the dawn of the $21^{\text {st }}$ century has now become the home of two rising powers - China and India, and a long-time economic power, Japan. Just as the $19^{\text {th }}$ century European powers involved in scramble for markets and resources elsewhere, these three Asian powers are pushing around for power and influence outweighing others; and this has its ramifications echoing in the multilateral bodies in which they participate. In essence, this is a paradigm of globalization articulating a reconfiguration of relations of economic and political power at the global level, what could be termed as geopolitics of globalization. Instead of craving for a European Union-model, the ASEAN-led regional bodies-particularly APT, JACIK and EAS - would do well to focus on ways of strengthening existing pan-regional activities in security and confidence-building, trade, monetary and financial 
cooperation, and improving transportation and communication links. "Greater regional cooperation is one of the few available instruments with which East Asian states can meet the double challenge of globalization from above and localization from below" (Yeo 2005). In pursuance of this goal, ASEAN needs to overcome its own narrow self-interested approach towards region-building and to be an honest broker desisting from the classical realist thinking of balancing role, by way of giving credence to the open regionalism and issue-led leadership.

\section{Notes}

(I) ACD is expected to constitute a missing link in Asia by incorporating every Asian country and building an Asian Community without duplicating other organizations or creating a bloc against others. The ACD has as of now 34 member states including 18 founder-members (Afghanistan, Bahrain, Bangladesh, Brunei Darussalam, Bhutan, Cambodia, China, India, Indonesia, Iran, Japan, Kazakhstan, Republic of Korea, Kuwait, Kyrgyz Republic, Lao PDR, Malaysia, Mongolia, Myanmar, Nepal, Pakistan, Philippines, Oman, Qatar, Russia, Saudi Arabia, Singapore, Sri Lanka, Tajikistan, Thailand, Turkey, United Arab Emirates, Uzbekistan and Vietnam). Yet, there are 18 Asian countries (excluding Egypt and Papua-New Guinea) which are yet to express their intent of joining ACD. Its aim to integrate separate regional cooperation organizations such as ASEAN, SAARC and the Gulf Cooperation Council is a challenge for ACD in view of the strong regional affiliations. ACD has its Ministerial Meetings held almost every year since its inception; and the last and $16^{\text {th }}$ Ministerial Meeting was held in Doha (Qatar) on 30 April 2019, while the last and $3^{\text {rd }}$ ACD summit was held in 2018 in Iran. See, for further details, http://www.acddialogue.org/index.html.

(II)After a gap of 10 years since the Bangkok Declaration of 1967, the first ever ASEAN Summit was held in February 1976 at Bali; and there was yet another gap of 10 years from the $2^{\text {nd }}$ Summit (Kuala Lumpur, August 1977) to the $3^{\text {rd }}$ Summit (Manila, December 1987), followed by a 5-year gap for the $4^{\text {th }}$ Summit (Singapore, January 1992). There were three consecutive gaps of 3 years -- the $5^{\text {th }}$ summit was held in December 1995 (Bangkok), the $6^{\text {th }}$ Summit in December 1998 (Hanoi) and the $7^{\text {th }}$ Summit in 2001 (Bander Seri Begawan). The Summit 
meetings have since 2001 been the regular annual feature, hosted by all member-states on rotation basis.

(III)ARF comprises the 10 ASEAN countries, the 10 ASEAN Dialogue Partners (Australia, Canada, China, the EU, India, Japan, New Zealand, ROK, Russia and the US), 1 one ASEAN Observer (PNG), as well as the DPRK, Mongolia, Pakistan, East Timor, Bangladesh and Sri Lanka.

(IV)The weaknesses of regional organizations in conflict management are vividly elaborated by Wulf (2009):

- Lack of common values: Political differences exist within regional organizations. The most obvious is the contrast between democratic and authoritarian governments. Religious, ethnic and cultural differences also pose barriers to a joint response.

- Contested sovereignty: Even non-military intervention contrasts with the principle of state sovereignty and the norm of non-intervention. Delegating authority to a regional body is opposed by many governments. The nation state's authority is jealously guarded.

- Overlapping responsibilities: The respective missions and geographic reach of regional and sub-regional organizations are unclear and often competitive. There is still no consensus about what is meant by the term region.

- Lack of capacity: Many regional organizations lack adequate institutions, procedures and capacity (human, material and financial). This makes it difficult to implement decisions and execute sanctions.

- Dominant regional powers: Some asymmetry in economic and military size exists in most regions. This can cause anxiety among neighbours. External powers have also left their mark in many regions.

\section{References}

Acharya, Amitav (2000), "Regional Institutions and Security Order in Asia," Presented at the Second Workshop on Security Order in the Asia-Pacific, Centre for Peace and Development Studies, Bali, 30 April - 2 May. 
Acharya, Amitav and Tan, See Seng (2006), "Betwixt balance and community: America, ASEAN, and the security of Southeast Asia," International Relations of the Asia-Pacific, 2006, 6(1): 37-59.

Bruce M. Russett (1967), International Regions and International Systems: a Study in Political Ecology, Rand McNally, Chicago.

Dutta, Ashok K. (1985), Southeast Asia: Realm of contrasts, third edn., Westview press, Boulder.

Fang, Yang (2011), South China Sea dispute: Why China takes a pragmatic stance, at http://www.eastasiaforum.org/2011/08/26/south-china-sea-dispute-why-china-takes-a-pragmaticstance/ (Accessed 19 September 2011).

Fawcett, Louise (1995), "Regionalism in Historical Perspective," in Louise Fawcett and Andrew Hurrell (eds.), Regionalism in World Politics, Oxford University Press, Oxford, pp. 9-36.

Fisher, Charles A. (1966), Southeast Asia: A Social, Economic and Political Geography, Methuen \& Co., London.

Higgott, Richard (1999), "The Political Economy of globalization in East Asia: The Salience of 'region building'," in Olds, Kris, Dicken P., Kelly, Philip F., Kong, Lily and Yeung, Henry Waichung (eds.), Globalization and the Asia-Pacific, Routledge, London.

Hurrell (eds.), Regionalism in World Politics, Oxford: Oxford University Press, London.

Job, Brian L. and Williams, Erin (2008), A Wake-Up to Southeast Asia: A Solution Call for Regional Multilateralism? at <www.cscap.org/uploads/docs/CRSO/CRSO\%202008.pdf> (accessed 17 September 2011).

Kacowicz, Arie M. (1998), "Regionalization, Globalization, and Nationalism: Convergent, Divergent, or Overlapping?" Paper presented at the IPSA Study Group II: "New World Orders?" Workshop on Globalisms and Regionalisms, Center for Development and the Environment, University of Oslo, Norway, 7 August.

Kesavapany, K. (2005), "A New Regional Architecture: Building the Asian Community," lecture presented at the Annual General Meeting of the Asian Institute of Transport Development, New Delhi, 31 March.

Koh, Tommy (2010), Building fraternity amongst East Asian states, 8 April 2010, at <http://www.eastasiaforum.org/2010/04/08/building-fraternity-amongst-east-asian-states/> (Accessed on 12 September 2011). 
Malik, Mohan (2007), "The East Asia Community and the Role of External Powers: Ensuring Asian Multilateralism is not Shanghaied," The Korean Journal of Defense Analyses, XIX (4), winter, pp. 29-50.

Palmer, Norman D. (1991), The New Regionalism in Asia and the Pacific, (chap.1), D.C. Heath \& Co., Pennsylvania.

Rajan, D.S. (2011), East Asia Integration - China's Reservations on India Playing a Leading Role, C3S Paper No.757, 13 March.

Richardson, Michael (2005), "Australia-Southeast Asia relations and the East Asian Summit," Australian Journal of International Affairs, 59 (3), September, pp. 351-65.

Severino, Rodolfo C. (2011), ASEAN Regional Forum expected to take up vital regional issues, at <http://www.eastasiaforum.org/2011/07/20/asean-regional-forum-expected-to-take-up-vitalregional-issues/> (Accessed 18 September 2011).

Singh, Daljit (2011), South China Sea developments at the ASEAN Regional Forum, at <www. eastasiaforum.org/2011/08/03/south-china-sea-developments-at-the-asean-regional-forum> (Accessed 27 September 2011).

Tan, See Seng (2011), ASEAN Regional Forum at 18: Dealing with Regional Flashpoints, at <www.eastasiaforum.org/2011/07/22/asean-regional-forum-at-18-dealing-with-regionalflashpoints> (Accessed 25 Sepember 2011).

Terada, Takashi (2011), 'ASEAN's talk shop function and US engagement,' at <www. eastasiaforum.org/2011/08/10/asean-s-talk-shop-function-and-us-engagement> (Accessed 26 September 2011).

Yagama Reddy, Y. (2004), "Geographical Causation in Southeast Asian History," Journal of Contemporary Asia and Europe, Vol.1, No.2, July-December, pp. 81-97.

Yagama Reddy, Y. (2005), "The Fossilized Indian Culture in Toponyms and the Enigmatic Etymology of the Term: Southeast Asia," The Asianists' Asia (Paris), Volume IV, spring.

Yeo, Lay Hwee, (2005), Realism and Reactive Regionalism: Where Is East Asian Regionalism Heading? UNISCI Papers, Singapore Institute of International Affairs, Singapore, May.

Wulf, H. (2009), "The Role of Regional Organizations in Conflict Prevention and Resolution," in H. Wulf (ed.), Still Under Construction: Regional Organisations' Capacities for Conflict Prevention, INEF Report, no. 97, Institute for Development and Peace, University of DuisburgEssen, Duisburg, pp. 5-19. 